\title{
Perception of toothache in adults from state capitals and interior cities within the Brazilian geographic regions
}

Maylu Botta Hafner*, Juliana Zanatta, Vera Lucia Rasera Zotelli, Marília Jesus Batista and Maria da Luz Rosário Sousa

\begin{abstract}
Background: Studies emphasizing toothache in adulthood are scarce in Brazil. A greater understanding of both the prevalence and the self-perception of pain among individuals in this age group (35 to 44 years old) is important, especially considering that this is an economically active population. To describe reports of oral pain and oral pain-related aspects in from Brazilian state capitals and interior cities.
\end{abstract}

Methods: The sample comprised 9779 adults residing in the state capitals and interior cities from each Brazilian region in the SB Brazil 2010 report, regarding reports of oral pain and their intensity in the last 6 months. The descriptive analysis comparing pain reports between and within the regions and regression analysis of pain related to socioeconomic aspects per region were performed considering $a=0.05$ difference.

Results: The highest prevalence of pain was found in the Southeast region $(p<0.01)$, and there was also difference between the state capitals and interior cities in the South $(p<0.01)$, where the prevalence was higher in the capitals, and in the Southeast, where the higher prevalence was in the interior cities $(p=0.03)$. The Northern region had lower pain intensity than the Southeast and Midwest. Comparing pain intensity, only the Northeast region showed statistical difference between state capitals and the interior cities for pain intensity, where the interior cities had higher pain intensity than the three state capitals. Regarding dental office visitations, the Southeast capitals have the highest prevalence (100\%) compared to the North and South. The toothache impact on daily activities was as follows: eating difficulty (29.8\% to $72.7 \%$ ), uncomfortable teeth brushing (over $50 \%$ ), and sleep disturbance (above 13\%). Between the Brazilian regions the socioeconomic aspects differ in relation to the pain; the exception being the association between pain, dental care and income, which occurred in the 5 regions. Users of public dental care services were more likely to present pain, comparing to private dental services, OR ranging from 1.72 in the Northeast to 2.85 in the Southeast.

Conclusion: The prevalence of pain was higher among Brazilian adults, impacting some of the daily activities. The data also showed many differences in the prevalence and intensity of pain among both the Brazilian regions and the cities within the same region.

Keywords: Toothache, Oral health, Epidemiological survey, Behavior

\footnotetext{
* Correspondence: mayluhafner@yahoo.com.br

Department of Social Dentistry/Psychology Applied to Dentistry, University of Campinas-UNICAMP, Piracicaba Dental School (FOP), Av. Limeira, 901-Bairro Areião, CEP: 13414-903, Piracicaba, SP, Brazil
}

\section{Biomed Central}

(c) 2013 Botta Hafner et al.; licensee BioMed Central Ltd. This is an Open Access article distributed under the terms of the Creative Commons Attribution License (http://creativecommons.org/licenses/by/2.0), which permits unrestricted use, distribution, and reproduction in any medium, provided the original work is properly cited. 


\section{Background}

The International Association for the Study of Pain (IASP) defines pain as an unpleasant sensory and emotional experience associated with actual or potential tissue damage [1]. Pain is always subjective, and individuals learn the application of the word pain through their experiences with injuries suffered since birth [2].

The World Health Organization (WHO) recognizes that pain, suffering, psychological constraints, and social deprivation may result from oral diseases; thus, causing damages at both the individual and the collective levels [3].

Toothache is one of the most common reasons for visiting the dentist [4], since it prevents or hinders daily activities, such as work, play, or interpersonal relationships $[5,6]$.

Despite these limitations caused by pain from dental origin, it takes people, on average, 60 days to consult a professional after the onset of a toothache [7]; thus, resulting in extractions in more than half of the cases [8].

Studies emphasizing toothache in adulthood are scarce in Brazil. A greater understanding of both the prevalence and the self-perception of pain among individuals in this age group ( 35 to 44 years old) is important, especially considering that this is an economically active population. More precise information on these epidemiological data would allow better targeting of resources for the employment of prevention policies in public health, which could contribute not only to improve the quality of oral health, but also to reduce absenteeism, since tooth pain is the third cause of work absenteeism [9].

Therefore, this paper aims to describe and compare reports of pain and pain-related aspects in adults (35 to 44 years of age) who live in Brazilian state capitals and interior cities located in each of the 5 geographic regions (North, Northeast, Southeast, Midwest, and South).

\section{Methods}

The sample comprised 9779 adults aged 35 to 44 years, of both sexes, being 7333 individuals from state capitals, and the remaining from interior cities. This age group was established as default, by the WHO, for assessing oral health conditions in adults [10].

The data used in the study were collected by trained teams in 27 capital and interior cities from every Brazilian state. Their training consisted of 16 hours of theory, and 20 hours of practice in oral health variables used in the Oral Health Epidemiological Survey-SB Brazil 2010 [11]. Examiners only collect data after obtaining an acceptable degree of uniformity in the procedures, according to the standards set by the WHO [12].

The teams used Personal Digital Assistants (PDAs) for data recording. The data collectors visited randomly selected households, using toothache and oral health care questionnaires.
Each participant signed an informed consent form. This project was approved by the Brazilian National Commission on Research Ethics (CONEP), registration no. 15498.

The data were obtained from the SB Brazil 2010 data bank, which collected them in Brazilian state capitals, divided by regional groups (North, Northeast, Midwest, Southeast, and South), and interior cities from each state. The reports of pain and related aspects were investigated in each region.

This study focused on the pain and its intensity for the last 6 months. For the "reporting pain" variable, the possible answers were: "Yes", "no" or "do not know". For the "pain intensity" variable, the answers were arranged in a numerical scale from 1 to 5 , with 1 for the least pain, and 5 for the highest self-reported pain. For this last variable, subjects who answered "no" or "do not know" were excluded.

The variables analyzed were: use of dental services (dental appointments, toothache consultation, and type of treatment), and pain interference with daily activities (pain while eating or drinking, discomfort when brushing, sleeping disturbance, work and/or study affected by the toothache).

These variables were recorded and allocated into categories. The dental appointment variable was dichotomized as "yes" and "no"; the use of dental services as "public" and "private"; reason for dental appointment as "pain" and "others". The variables: difficulty eating, uncomfortable brushing, and sleep disturbance caused by teeth discomforts were dichotomized into "yes" or "no".

The demographic and socioeconomic variables in this study were gender (male and female), income (under R\$ 250 , between $R \$ 250$ and $R \$ 750$ and above $R \$ 750$ ), education ( 8 years, 8 years or more), and residents per room (less than 2 residents per room, 2 residents per room or more).

A descriptive analysis was initially performed with separate datafrom the state capitals and other cities. Descriptive statistics, chi square, one-way ANOVA, and the Tukey test were used to assess differences between pain prevalence and its intensity in the Brazilian regions $(\alpha=0.05)$. Binary logistic regression analysis was performed for each macro region of Brazil, with the outcome being pain (pain either reported or unreported in the past 6 months), in addition to the independent variables: gender, geographic location (interior cities or capitals), income, education, residents per room, and type of dental service. Variables with $\mathrm{p}<0.2$ were included in the regression model, considering the $\mathrm{p}<0.05$ significance level.

\section{Results}

Table 1 shows the prevalence of pain in the last 6 months, the average pain intensity in Brazilian adults, and a comparison between the capitals and the interior cities, divided 
into the North, Northeast, Midwest, Southeast, and South regions.

The prevalence of toothache in Brazil reached more than a quarter of the population (21\%), with a pain intensity of 3.2 (0 to 5). The highest prevalence of pain (over 30\% of the population) was found not only in the Southeast cities, but also in the state capitals of Boa Vista, Recife, and São Paulo. These results were inconsistent with São Luis, where the prevalence of pain reached less than $15 \%$ of the population. The capitals with the highest prevalence of pain also had the highest pain intensity.

The higher prevalence of pain was found in the Southeast, differing statistically from the pain found in other regions $(\mathrm{p}<0.01)$. The intra region analyses found difference in prevalence between the capitals and the interior cities from the South and Southeast regions, but in different ways. In the South, the capitals presented higher prevalence of pain.

Table 1 Comparison of prevalence and pain intensity in the last 6 months of Brazilian regions

\begin{tabular}{|c|c|c|c|c|c|c|c|}
\hline & & $\begin{array}{l}\text { Percentage pain } \\
6 \text { months }(\mathrm{N})\end{array}$ & $\begin{array}{l}\text { Capital versus } \\
\text { interior } p \text {-value* }\end{array}$ & $\begin{array}{l}\text { Prevalence } \\
\text { per region** }\end{array}$ & $\begin{array}{c}\text { Intensity } \\
\text { average }\end{array}$ & $\begin{array}{l}\text { Capital versus } \\
\text { interior } \mathrm{p} \text {-value* }\end{array}$ & $\begin{array}{l}\text { Intensity average } \\
\text { per region }\end{array}$ \\
\hline \multirow[t]{8}{*}{ North } & Belém & $25.60 \%(127)$ & 0.05 & $22.63 \%^{\mathrm{A}}$ & 3.30 & 0.38 & $3.25^{\mathrm{A}}$ \\
\hline & Boa Vista & $31.10 \%(57)$ & & & 3.45 & & \\
\hline & Macapá & $24.80 \%(85)$ & & & 3.25 & & \\
\hline & Manaus & $15.70 \%(36)$ & & & 3.27 & & \\
\hline & Palmas & $18.80 \%(59)$ & & & 3.01 & & \\
\hline & Porto Velho & $20.80 \%(67)$ & & & 3.38 & & \\
\hline & Rio Branco & $19.40 \%(41)$ & & & 2.89 & & \\
\hline & Inner North & $26.77 \%(125)$ & & & 3.48 & & \\
\hline \multirow[t]{10}{*}{ Northeast } & Aracaju & $20.10 \%(43)$ & 0.21 & $24.16 \%^{\mathrm{A}}$ & $2.81^{\mathrm{A}}$ & 0.00 & $3.28^{\mathrm{AB}}$ \\
\hline & Fortaleza & $25.70 \%(95)$ & & & $3.42^{\mathrm{AB}}$ & & \\
\hline & João Pessoa & $21.70 \%(46)$ & & & $3.43^{\mathrm{AB}}$ & & \\
\hline & Maceió & $24.20 \%(45)$ & & & $3.31^{\mathrm{AB}}$ & & \\
\hline & Natal & $26.90 \%(47)$ & & & $2.97^{\mathrm{A}}$ & & \\
\hline & Recife & $31.50 \%(45)$ & & & $3.51^{\mathrm{AB}}$ & & \\
\hline & Salvador & $24.50 \%(67)$ & & & $3.58^{\mathrm{AB}}$ & & \\
\hline & São Luis & $13.40 \%(21)$ & & & $3.14^{\mathrm{AB}}$ & & \\
\hline & Teresina & $27.50 \%(75)$ & & & $3.09^{\mathrm{A}}$ & & \\
\hline & Inner Northeast & $27.00 \%(115)$ & & & $3.88^{\mathrm{B}}$ & & \\
\hline \multirow[t]{5}{*}{ Southeast } & Belo Horizonte & $27.00 \%(70)$ & 0.03 & $27.87^{\mathrm{B}}$ & 3.35 & 0.61 & $3.55^{\mathrm{B}}$ \\
\hline & Rio de Janeiro & $18.50 \%(60)$ & & & 3.45 & & \\
\hline & São Paulo & $36.00 \%(132)$ & & & 3.67 & & \\
\hline & Vitória & $29.70 \%(46)$ & & & 3.67 & & \\
\hline & Inner Southeast & $32.99 \%(161)$ & & & 3.60 & & \\
\hline \multirow[t]{4}{*}{ South } & Curitiba & $22.10 \%(92)$ & 0.00 & $25.73 \%^{\mathrm{A}}$ & 3.20 & 0.31 & $3.38^{\mathrm{AB}}$ \\
\hline & Florianópolis & $28.30 \%(62)$ & & & 3.50 & & \\
\hline & Porto Alegre & $28.00 \%(120)$ & & & 3.46 & & \\
\hline & Inner South & $18.05 \%(102)$ & & & 3.15 & & \\
\hline \multirow[t]{5}{*}{ Midwest } & Brasília & $23.20 \%(52)$ & 0.27 & $21.09 \%^{\mathrm{A}}$ & 3.65 & 0.17 & $3.58^{\mathrm{B}}$ \\
\hline & Campo Grande & $18.00 \%(68)$ & & & 3.67 & & \\
\hline & Cuiabá & $17.60 \%(28)$ & & & 3.03 & & \\
\hline & Goiânia & $26.00 \%(65)$ & & & 3.67 & & \\
\hline & Inner Midwest & $23.60 \%(112)$ & & & 3.38 & & \\
\hline Brazil & & $21.00 \%(2367)$ & & $0.00^{*}$ & 3.20 & & $0.00^{* *}$ \\
\hline
\end{tabular}


Regarding pain intensity, the capitals: Rio Branco (North), Aracaju, and Natal (Northeast) have the lowest averages (less than 3.0), although their percentages of pain complaints in the last six months were not the lowest.

There was a statistical difference for pain intensity among Brazilian regions $(\mathrm{p}<0.01)$. It was possible to observe that the reported pain intensity in the Northern region (3.25) was statistically lower than in the Southeast (3.5) and Midwest (3.58) regions, where there were reports of higher intensity.

There were also differences in pain intensity in the analysis between capital and interior cities in the Northeast region $(\mathrm{p}<0.01)$. The pain intensity in the interior cities was statistically higher than in the capitals of Teresina (3.09), Natal (2.97), and Aracaju (2.81).

Table 2 shows the aspects related to toothache in the adult population who complained of toothache in the six months prior to the survey. These aspects relate to the search of dental services, and the possible consequences of toothache in daily activities.

Regarding "dental appointment", the Southeast capitals had the highest percentages (100\%) compared to the North, Northeast, and South capitals. The North and South capitals had the lowest demand for dental appointment.

Concerning "use of public dental services", it was noteworthy that in 13 Brazilian capitals, the demand for these services was above $50 \%$, most of them in the North and Northeast regions. In the interior cities of the Southeast and South regions, the demand for such services was less than $50 \%$.

For "pain as reason for the visit" the percentage ranged from 13.2\% (Rio Branco) to 54.8\% (Florianópolis). The interior cities from the North, South, and Midwest regions presented the highest values (above 30\%).

Among the variables related to toothache which impacted daily activities (eating difficulty, uncomfortable teeth brushing, and sleep disturbance) the difficulty in eating had the highest percentages, ranging from 29.8\% (Natal) to $72.7 \%$ (São Paulo). Regarding the "uncomfortable teeth brushing" we observed that in most cities (including the interior cities) fewer than $50 \%$ of adults who reported pain had this difficulty. For the "sleep disturbance" variable the values were above $13 \%$ in all municipalities, reaching the percentage of $57.6 \%$ in São Paulo (capital).

With regard to the socioeconomic status and the presence of pain, we observe in Table 3 that all regions presented an association between pain, income, and type of service in all regions. Those who had lower income had a higher prevalence of pain, with the OR varying from 1.69 (Northeast) to 2.88 (Southeast). Those who used public dental care were more likely to present pain, comparing to users of private dental services, with the OR ranging from 1.72 in the Northeast to 2.85 in the Southeast. The geographical location, either capital or interior cities, presented different directions in two regions. In the Southeast there was a higher prevalence of pain in the capitals while in the Northeast, the higher prevalence of pain was in the interior cities.

\section{Discussion}

The prevalence of pain in the last six months among Brazilian adults can reach up to one third of the adult population in some capitals and/or interior cities, with a mean of pain intensity of approximately 3.2 , characterized as a reference between "severe pain" and "very severe pain", according to Silva and Ribeiro-Filho [1]. Pain causes suffering and this study improves the knowledge about this condition, which impacts the active age population; thus, resulting in losses of productivity and decrease in the quality of life.

Despite the high intensity and prevalence of pain in the whole country, the analyses show uneven results between the neighboring regions. The South and Southeast regions have different behaviors in relation to the prevalence of pain, since the highest prevalence of pain in the Southern region is in the capitals, while in the Southeast it is in the interior cities. Perhaps the features of these regions are different or otherwise distributed.

Regarding pain intensity, there are differences between capitals and interior cities in the Northeast region. The interior cities show the highest intensity of pain, statistically different than three capitals. Once more it is possible to justify this difference by the distribution and access to dental resources in this region.

Gibilini et al., [13] surveyed 1612 adults in an epidemiological survey conducted by the Health Department of the State of São Paulo in conjunction with the School of Public Health, from the University of São Paulo (USP), according to the SB Brazil Project methodology. This study found that in the state of São Paulo (Southeast region) the prevalence of dental pain was $34.1 \%$, which indicates that one-third of this population had episodes of pain. According to our survey with the SB Brazil 2010, the data still show that both in the capital and in the interior cities from the state of São Paulo, the prevalence of pain reached one-third of the adult population.

Moreover, the prevalence of pain is high in the Southeast, which causes numerous problems of economic and social order. In the Southeast region there are more frequent visits to the dentist and disturbances caused by toothache. These data were different than the ones reported in another Brazilian study, which found a higher prevalence of pain in the North and Northeast capitals [14]. The geographical location, either interior cities or capitals, remained significant even after adjustments for demographic and socioeconomic variables in the Southeast and Northeast; however, the likelihood of having pain was higher in 
Table 2 Frequency of aspects related to pain in adults from Brazilian regions (last 6 months)

\begin{tabular}{|c|c|c|c|c|c|c|c|}
\hline & & $\begin{array}{l}\text { Went to the } \\
\text { dentist } \%(n)\end{array}$ & $\begin{array}{l}\text { Public dental } \\
\text { service \% (n) }\end{array}$ & $\begin{array}{c}\text { Reason-pain } \\
\%(n)\end{array}$ & $\begin{array}{l}\text { Difficulty in } \\
\text { eating\% ( } n)\end{array}$ & $\begin{array}{l}\text { Brushing discomfort } \\
\qquad \%(n)\end{array}$ & $\begin{array}{c}\text { Sleep disturbance } \\
\%(n)\end{array}$ \\
\hline \multirow[t]{8}{*}{ North } & Belém & $97.60 \%(122)$ & $49.20 \%(60)$ & $25.40 \%(31)$ & $56.70 \%(72)$ & $43.30 \%(55)$ & $34.90 \%$ (44) \\
\hline & Boa Vista & $98.20 \%(56)$ & $60.70 \%(34)$ & $41.10 \%(23)$ & $53.60 \%(30)$ & $49.10 \%(28)$ & $48.10 \%(26)$ \\
\hline & Macapá & $85.90 \%(73)$ & $68.50 \%(50)$ & $23.30 \%(17)$ & $63.50 \%(54)$ & $40.00 \%$ 34) & $48.20 \%(41)$ \\
\hline & Manaus & $100.00 \%(36)$ & $60.00 \%(21)$ & $25.70 \%(9)$ & $40.00 \%(14)$ & $37.10 \%(13)$ & $33.30 \%(12)$ \\
\hline & Palmas & $96.60 \%(56)$ & $50.00 \%(28)$ & $33.90 \%$ (19) & $57.60 \%$ 934) & $47.50 \%(28)$ & $20.30 \%(12)$ \\
\hline & Porto Velho & $98.50 \%(66)$ & $53.00 \%(35)$ & $30.30 \%(20)$ & $58.20 \%$ (39) & $46.30 \%(31)$ & $17.90 \%(12)$ \\
\hline & Rio Branco & $95.10 \%(39)$ & $64.10 \%(25)$ & $13.20 \%(5)$ & $47.50 \%(19)$ & $48.80 \%(20)$ & $19.50 \%(8)$ \\
\hline & Inner North & $90.40 \%$ (113) & $64.50 \%(71)$ & $35.10 \%(39)$ & $49.60 \%(61)$ & $44.40 \%(55)$ & $35.20 \%(43)$ \\
\hline \multirow[t]{10}{*}{ Northeast } & Aracaju & $100.00 \%(43)$ & $69.80 \%(30)$ & $18.60 \%(8)$ & $57.10 \%(24)$ & $37.20 \%(16)$ & $16.30 \%(7)$ \\
\hline & Fortaleza & $97.90 \%(92)$ & $44.60 \%(41)$ & $35.90 \%(33)$ & $62.10 \%(59)$ & $52.10 \%$ 949) & $35.80 \%$ (34) \\
\hline & João Pessoa & $91.30 \%(42)$ & $66.70 \%(28)$ & $33.30 \%(14)$ & $39.10 \%(18)$ & $37.00 \%(17)$ & $41.30 \%(19)$ \\
\hline & Maceió & $100.00 \%(45)$ & $34.10 \%(15)$ & $13.30 \%(6)$ & $59.10 \%(26)$ & $47.70 \%(21)$ & $48.90 \%(22)$ \\
\hline & Natal & $83.00 \%$ (39) & $53.80 \%(21)$ & $46.20 \%(18)$ & $29.80 \%(14)$ & $41.30 \%(19)$ & $14.90 \%(7)$ \\
\hline & Recife & $100.00 \%(45)$ & $51.10 \%(23)$ & $35.60 \%(16)$ & $60.00 \%(27)$ & $46.70 \%(21)$ & $44.40 \%(20)$ \\
\hline & Salvador & $92.50 \%(62)$ & $26.70 \%(16)$ & $27.90 \%(17)$ & $40.30 \%(27)$ & $28.80 \%(19)$ & $13.40 \%(9)$ \\
\hline & São Luis & $81.00 \%(17)$ & $29.40 \%(5)$ & $23.50 \%(4)$ & $66.70 \%(14)$ & $61.90 \%(13)$ & $35.00 \%(7)$ \\
\hline & Teresina & $93.30 \%(70)$ & $78.60 \%$ (55) & $28.60 \%(20)$ & $50.00 \%(37)$ & $32.00 \%(24)$ & $40.00 \%(30)$ \\
\hline & Inner Northeast & $91.70 \%$ (105) & $64.80 \%(68)$ & $28.80 \%(30)$ & $67.80 \%(78)$ & $48.70 \%(55)$ & $43.00 \%(49)$ \\
\hline \multirow[t]{5}{*}{ Southeast } & Belo Horizonte & $100.00 \%(70)$ & $31.40 \%(22)$ & $40.00 \%(28)$ & $63.80 \%(44)$ & $60.00 \%(42)$ & $30.00 \%(21)$ \\
\hline & Rio de Janeiro & $100.00 \%(60)$ & $41.70 \%(25)$ & $26.70 \%(16)$ & $61.00 \%(36)$ & $45.00 \%(27)$ & $27.10 \%(16)$ \\
\hline & São Paulo & $100.00 \%(131)$ & $42.70 \%(56)$ & $42.00 \%(55)$ & $72.70 \%(96)$ & $53.80 \%(71)$ & $57.60 \%(76)$ \\
\hline & Vitória & $100.00 \%(46)$ & $50.00 \%(23)$ & $39.10 \%(18)$ & $54.30 \%(25)$ & $40.90 \%(18)$ & $28.30 \%(13)$ \\
\hline & Inner Southeast & $94.40 \%$ (152) & $49.30 \%(75)$ & $26.30 \%(40)$ & $53.30 \%(90)$ & $52.50 \%(84)$ & $44.10 \%(71)$ \\
\hline \multirow[t]{4}{*}{ South } & Curitiba & 91.30\% (84) & $52.40 \%(44)$ & $38.10 \%(32)$ & $51.10 \%(47)$ & $37.00 \%$ (34) & $29.30 \%(27)$ \\
\hline & Florianópolis & $100.00 \%(62)$ & $53.20 \%(33)$ & $54.80 \%(34)$ & $38.70 \%(24)$ & $46.80 \%(29)$ & $30.60 \%(19)$ \\
\hline & Porto Alegre & $98.30 \%(118)$ & $48.30 \%(57)$ & $33.90 \%(40)$ & $65.00 \%(78)$ & $47.90 \%(57)$ & $52.50 \%(63)$ \\
\hline & Inner South & $94.10 \%(95)$ & $49.50 \%(47)$ & $32.60 \%(31)$ & $57.80 \%(59)$ & $40.20 \%(41)$ & $32.40 \%$ (33) \\
\hline \multirow[t]{5}{*}{ Midwest } & Brasília & $94.20 \%(49)$ & $32.70 \%(16)$ & $32.70 \%(16)$ & $69.20 \%(36)$ & $50.00 \%(26)$ & $51.90 \%(27)$ \\
\hline & Campo Grande & $98.50 \%(67)$ & $62.70 \%(42)$ & $52.20 \%(35)$ & $61.80 \%(42)$ & $41.20 \%(28)$ & $38.20 \%(26)$ \\
\hline & Cuiabá & $92.90 \%(26)$ & $38.50 \%(10)$ & $30.80 \%(8)$ & $46.40 \%(13)$ & $39.30 \%(11)$ & $25.00 \%(7)$ \\
\hline & Goiânia & $92.30 \%(60)$ & $30.00 \%(18)$ & $43.30 \%(26)$ & $53.80 \%(35)$ & $32.30 \%(21)$ & $37.50 \%(24)$ \\
\hline & Inner Midwest & $88.40 \%$ (99) & $60.60 \%(60)$ & $30.30 \%$ (30) & $60.40 \%(67)$ & $47.30 \%(52)$ & $45.50 \%(51)$ \\
\hline
\end{tabular}

the Northeast interior cities, and in the Southeast capitals. The migration of Northeasterners to the Southeast in search of better jobs and life opportunities is a noteworthy phenomenon. This fact demonstrates the heterogeneity among Brazilian regions as well as within the regions, between capitals and interior cities, which may have different characteristics in relation to the access to dental services.

A toothache seems to be disabling for the main function-eating-peaking at $72 \%$ of the population in São Paulo (capital). This same city reported the highest occurrence of sleep disturbance caused by toothache
(57.6\%), which can compromise the quality of life of individuals.

For the suffering and limitations it causes, the pain has a major impact in the daily life; thus, having a dramatic effect on society due to the high cost of treatment, and the loss in productivity [15].

In a cross-sectional study with 276 adults from Porto Alegre (South region) in 2005, Gomes and Abegg (2007) [16] described that $73.6 \%$ of those reported at least one daily activity affected by dental problems in the past six months. The most affected performance was also related to the eating function (48.6\%), followed by a difficulty 
Table 3 Demographic and socioeconomic aspects related to pain in adults from Brazilian regions (last 6 months), Brazil, 2010

\begin{tabular}{|c|c|c|c|c|c|c|c|c|c|c|}
\hline & Variables & & No pain $\mathrm{n} \%$ & Pain $\mathrm{n} \%$ & OR crude & $95 \% \mathrm{Cl}$ & $p$ & OR adjusted & $95 \% \mathrm{Cl}$ & $p$ \\
\hline \multirow[t]{13}{*}{ North } & Dental service & Public & $739(42.6)$ & $324(58.2)$ & 1.87 & $1.54-2.27$ & $<0.01$ & 1.52 & $1.23-1.87$ & $<0.01$ \\
\hline & & Private & $994(57.4)$ & $233(41.8)$ & 1 & & & 1 & & \\
\hline & Education & Up to 8 years & $771(39.7)$ & $303(51.7)$ & 1.63 & $1.35-1.96$ & $<0.01$ & 1.28 & $1.04-1.57$ & 0.02 \\
\hline & & $>8$ years & $1173(60.3)$ & $283(48.3)$ & 1 & & & 1 & & \\
\hline & Income & Up to 250 & $274(14.3)$ & $123(20.8)$ & 2.37 & $1.78-3.16$ & $<0.01$ & 1.86 & $1.34-2.58$ & $<0.01$ \\
\hline & & $250-750$ & $985(51.3)$ & $343(58.0)$ & 1.84 & $1.47-2.31$ & $<0.01$ & 1.54 & $1.20-1.98$ & $<0.01$ \\
\hline & & More than 750 & $661(34.4)$ & $125(21.2)$ & 1 & & & 1 & & \\
\hline & Sex & Female & $1228(62.8)$ & $399(66.8)$ & 1.2 & $0.98-1.45$ & 0.07 & & & \\
\hline & & Male & $728(37.2)$ & $198(33.2)$ & 1 & & & & & \\
\hline & Resident per room & 2 or more & $608(31.1)$ & $222(37.2)$ & 1.31 & $1.08-1.59$ & $<0.01$ & & & \\
\hline & & Up to 2 & $1347(68.9)$ & $375(62.8)$ & & & & & & \\
\hline & Location & Interior & $342(17.5)$ & $125(20.9)$ & 1.25 & $0.99-1.57$ & 0.05 & & & \\
\hline & & Capital & $1614(82.5)$ & $472(79.1)$ & & & & & & \\
\hline \multirow[t]{13}{*}{ Northeast } & Dental service & Public & $321(31.2)$ & $201(43.8)$ & 1.72 & $1.38-2.16$ & $<0.01$ & 1.4 & $1.10-1.79$ & $<0.01$ \\
\hline & & Private & $709(68.8)$ & $258(56.2)$ & 1 & & & 1 & & \\
\hline & Education & Up to 8 years & $553(49.4)$ & $280(60.1)$ & 1.54 & $1.24-1.92$ & $<0.01$ & 1.31 & $1.02-1.67$ & 0.03 \\
\hline & & $>8$ years & $567(50.6)$ & $186(39.9)$ & 1 & & & 1 & & \\
\hline & Income & Up to 250 & $125(11.4)$ & $72(15.8)$ & 1.57 & $1.22-2.02$ & $<0.01$ & 1.87 & $1.25-2.80$ & $<0.01$ \\
\hline & & $250-750$ & $576(52.7)$ & $267(58.7)$ & 1.95 & $1.36-2.79$ & $<0.01$ & 1.32 & $1.01-1.74$ & 0.04 \\
\hline & & More than 750 & $393(35.9)$ & $116(25.5)$ & 1 & & & 1 & & \\
\hline & Sex & Female & $710(63.2)$ & $344(73.3)$ & 1.61 & $1.61-2.04$ & $<0.01$ & 1.54 & $1.20-1.98$ & $<0.01$ \\
\hline & & Male & $414(36.8)$ & $125(26.7)$ & 1 & & & 1 & & \\
\hline & Resident per room & 2 or more & $447(39.8)$ & $227(48.4)$ & 1.42 & $1.14-1.77$ & $<0.01$ & & & \\
\hline & & Up to 2 & $677(60.2)$ & $242(51.6)$ & 1 & & & & & \\
\hline & Location & Interior & $327(29.1)$ & $161(34.3)$ & 1.27 & $1.01-1.06$ & 0.03 & 1.34 & $1.04-1.72$ & 0.02 \\
\hline & & Capital & 797 (70.9) & $308(65.7)$ & & & & & & \\
\hline \multirow[t]{13}{*}{ Southeast } & Dental service & Public & $317(26.3)$ & $181(50.4)$ & 2.85 & $1.24-3.64$ & $<0.01$ & 2.5 & $1.93-3.26$ & $<0.01$ \\
\hline & & Private & $889(73.7)$ & $178(49.6)$ & 1 & & & & & \\
\hline & Education & Up to 8 years & $475(38.0)$ & $190(50.5)$ & 1.67 & $1.32-2.10$ & $<0.01$ & & & \\
\hline & & $>8$ years & $775(62.0)$ & $186(49.5)$ & 1 & & & & & \\
\hline & Income & Up to 250 & $58(4.7)$ & $42(11.4)$ & 3.7 & $2.39-5.72$ & $<0.01$ & 2.88 & $1.79-4.65$ & $<0.01$ \\
\hline & & $250-750$ & $469(37.9)$ & $188(50.9)$ & 2.05 & $1.60-2.62$ & $<0.01$ & 1.68 & $1.28-2.20$ & $<0.01$ \\
\hline & & More than 750 & $709(57.4)$ & $139(37.7)$ & 1 & & & 1 & & \\
\hline & Sex & Female & $803(64.0)$ & $263(69.9)$ & 1.31 & $1.02-1.68$ & 0.03 & & & \\
\hline & & Male & $451(36.0)$ & $113(30.1)$ & 1 & & & & & \\
\hline & Resident per room & 2 or more & $287(22.9)$ & 119 (31.6) & 1.56 & $1.21-2.01$ & $<0.01$ & & & \\
\hline & & Up to 2 & $967(77.1)$ & $257(68.4)$ & 1 & & & & & \\
\hline & Location & Interior & $463(36.9)$ & $102(27.1)$ & 0.64 & $0.49-0.82$ & $<0.01$ & 0.51 & $0.39-0.67$ & $<0.01$ \\
\hline & & Capital & $791(63.1)$ & $274(72.9)$ & & & & 1 & & \\
\hline \multirow[t]{3}{*}{ South } & Dental service & Public & $373(34.4)$ & $146(48.5)$ & 1.8 & $1.39-2.31$ & $<0.01$ & 1.61 & $1.23-2.11$ & $<0.01$ \\
\hline & & Private & $712(65.6)$ & $155(51.5)$ & 1 & & & 1 & & \\
\hline & Education & Up to 8 years & $562(48.8)$ & $196(60.9)$ & 1.63 & $1.27-2.10$ & $<0.01$ & & & \\
\hline
\end{tabular}


Table 3 Demographic and socioeconomic aspects related to pain in adults from Brazilian regions (last 6 months), Brazil, 2010 (Continued)

\begin{tabular}{|c|c|c|c|c|c|c|c|c|c|c|}
\hline & & $>8$ years & $590(51.2)$ & $126(39.1)$ & 1 & & & & & \\
\hline & \multirow[t]{3}{*}{ Income } & Up to 250 & $128(11.4)$ & 65 (20.6) & 2.61 & $1.78-3.82$ & $<0.01$ & 2.29 & $1.51-3.48$ & $<0.01$ \\
\hline & & $250-750$ & $581(51.6)$ & $170(53.8)$ & 1.5 & $1.12-2.02$ & $<0.01$ & 1.36 & $1.00-1.85$ & 0.04 \\
\hline & & More than 750 & $416(37.0)$ & 81 (25.6) & 1 & & & 1 & & \\
\hline & \multirow[t]{2}{*}{ Sex } & Female & $757(65.3)$ & $227(69.8)$ & 1.23 & $0.95-1.61$ & 0.12 & & & \\
\hline & & Male & $403(34.7)$ & $98(30.2)$ & 1 & & & & & \\
\hline & \multirow[t]{2}{*}{ Resident per room } & 2 or more & $394(34.0)$ & $134(41.2)$ & 1.36 & $1.06-1.76$ & 0.01 & & & \\
\hline & & Up to 2 & $766(66.0)$ & $191(58.8)$ & 1 & & & & & \\
\hline & \multirow[t]{2}{*}{ Location } & Interior & $363(31.3)$ & $112(34.5)$ & 1.15 & $0.89-1.50$ & 0.27 & & & \\
\hline & & Capital & $797(68.7)$ & $213(65.5)$ & 1 & & & & & \\
\hline \multirow[t]{13}{*}{ Midwest } & \multirow[t]{2}{*}{ Dental service } & Public & $648(39.4)$ & $302(54.2)$ & 1.82 & $1.50-2.21$ & $<0.01$ & 1.33 & $1.08-1.65$ & $<0.01$ \\
\hline & & Private & 995 (60.6) & $255(45.8)$ & 1 & & & 1 & & \\
\hline & \multirow[t]{2}{*}{ Education } & Up to 8 years & $676(37.1)$ & $328(55.1)$ & 2.08 & $1.73-2.51$ & $<0.01$ & 1.59 & $1.28-1.97$ & $<0.01$ \\
\hline & & $>8$ years & 1145 (62.9) & $267(44.9)$ & & & & & & \\
\hline & \multirow[t]{3}{*}{ Income } & Up to 250 & $344(19.3)$ & $181(30.8)$ & 2.91 & $2.21-3.83$ & $<0.01$ & 2.12 & $1.55-2.91$ & $<0.01$ \\
\hline & & $250-750$ & $860(48.3)$ & $302(51.4)$ & 1.94 & $1.52-2.48$ & $<0.01$ & 1.65 & $1.26-2.16$ & $<0.01$ \\
\hline & & More than 750 & $575(32.3)$ & $104(17.7)$ & 1 & & & 1 & & \\
\hline & \multirow[t]{2}{*}{ Sex } & Female & $1176(64.3)$ & $437(73.0)$ & 1.5 & $1.22-1.84$ & $<0.01$ & 1.5 & $1.20-1.87$ & $<0.01$ \\
\hline & & Male & $654(35.7)$ & $162(27.0)$ & 1 & & & 1 & & \\
\hline & \multirow[t]{2}{*}{ Resident per room } & 2 or more & $666(36.4)$ & $247(41.2)$ & 1.23 & $1.02-1.48$ & 0.03 & & & \\
\hline & & Up to 2 & 1164 (63.6) & $352(58.8)$ & 1 & & & & & \\
\hline & \multirow[t]{2}{*}{ Location } & Interior & $311(17.0)$ & $115(19.2)$ & 1.16 & $0.92-1.47$ & 0.21 & & & \\
\hline & & Capital & 1519 (83.0) & $484(80.8)$ & 1 & & & & & \\
\hline
\end{tabular}

in performing oral hygiene (38.4\%). In this study, the data showed that in this same city, the difficulties in eating and teeth brushing had the highest percentages (65\% and $47.9 \%$, respectively).

The demand for public dental services was the highest in the North, and the Northeast regions. This same distribution has been described by Pinto et al., [17] when analyzing the data from the SB Brazil 2003 project. They highlighted the factors associated with the demand for public dental services by the Brazilian adult population, which indicate that in the above mentioned areas the percentage of demand for public dental services was above $60 \%$. The results suggest the probability that in these regions, the public service is the main form of dental care available to the population. These regions have a large low-income population, who depend on public health services. Therefore, people seek the services only on an emergency basis, in the presence of pain.

The type of dental services was associated with the presence of pain in the five Brazilian regions, and the users of public services had a higher prevalence of pain. It is noteworthy that in the Southeast, the likelihood of pain was more prevalent, and the use of public services was higher, compared to the private sector. Lacerda et al. [4] observed a higher prevalence of pain among adults who did not use the dental services provided by their employers; however, according to Bastos et al., [18] the influence of health services needs further clarification, since their attitude may be affected by the social environment, such as home, school, and work.

The perception of pain can be associated with demographic and socioeconomic characteristics as demonstrated in the present study, and others $[4,18]$. In the present study, women had a higher prevalence of pain in the Northeast and Midwest, but according to Peres et al., [14] the dental pain was higher among Brazilian men. With respect to income and education as socioeconomic factors, there was an association between pain and income in all Brazilian regions and in some regions such as the North, Northeast and the Midwest, education levels was also associated with pain, according to Lacerda et al., [4].

The association of socioeconomic factors with pain highlights the role of social inequalities in health care, since dental pain is strongly associated with oral diseases, mainly the decay [18]. Income and education are determinants of health, and it is proven that individuals 
who find themselves in situations of socioeconomic disadvantages are at a higher risk of developing oral diseases [19,20], and to suffer dental pain because of these diseases.

The higher prevalence of pain and its intensity across the country results from a curative health policy, which aims at solving the problems instead of preventing them. Thus, future studies should address the factors directly linked to the subjective aspect of pain, as well as seeking ways to minimize their impact on the lives of individuals. This high prevalence and intensity of reported pain in adults indicate the need to encourage awareness and/or perception of dental problems at an earlier stage, favoring a preventive approach instead of the emergency curative, now present in this segment of the population.

\section{Conclusions}

The prevalence and intensity of pain were higher among Brazilian adults, both in capitals and interior cities, as well as the impact on some activities performed by these individuals. The differences found between regions and between capitals and interior cities are many, showing an unequal country regarding health care. New public policies should be directed to prevent episodes of dental pain in all Brazilian regions.

\section{Competing interests}

The authors declare that they have no competing interests.
9. Miotto MHMB, Silotti JCB, Barcellos LA: Dor dentária como motivo de absenteísmo em uma população de trabalhadores. Ciência e saúde coletiva [online] 2012, 17(5):1357-1363.

10. Ministério da Saúde: Projeto SB 2003: condições de saúde bucal da população brasileira 2002-2003. Rio de Janeiro.

11. Ministério da Saúde: Projeto SB 2010: condições de saúde bucal da população brasileira 2009-2010. Rio de Janeiro.

12. World Health Organization (WHO): Calibration of examiners for oral health epidemiological surveys. Geneva: World Health Organization; 1993.

13. Gibilini C, Esmeriz CEC, Volpato LF, et al: Acesso a serviços odontológicos e auto-percepção de saúde bucalem adolescentes, adultos e idosos. Arquivos em Odontologia 2010, 46(4):213-223.

14. Peres MA, Iser BPM, Peres KG, et al: Desigualdades contextuais e individuais da prevalência de dor dentária em adultos e idosos no Brasil. Cad Saúde Pública 2012, 28(Sup):114-123.

15. Macfarlane TV, Blinkhorn AS, Davies RM, et al: Orofacial pain: just another chronic pain? Results from a population-based survey. Pain 2002, 99(3):453-458

16. Gomes AS, Abegg C: O impacto odontológico no desempenho diário dos trabalhadores do Departamento Municipal de Limpeza Urbana de Porto Alegre, Rio Grande do Sul, Brasil. Cad Saúde Pública 2007, 23(7):1707-1714.

17. Pinto RS, Matos DL, Loyola Filho Al: Características associadas ao uso de serviços odontológicos públicos pela população adulta brasileira. Ciência Saúde Coletiva 2012, 17(2):531-544.

18. Bastos JLD, Gigante DP, Peres KG, et al: Determinação social da odontalgia em estudos epidemiológicos: revisão teórica e proposta de um modelo conceitual. Ciência Saúde Coletiva 2007, 12(6):1611-1621.

19. Marmot M: Social Determinants of health inequalities. Lancet 2005, 365(9464):1099-1104.

20. Sheiham A, Alexander D, Cohen L, et al: Global Oral Health Inequalities: Task Group-Implementation and delivery of oral health strategies. Adv Dent Res 2011, 23(2):259-267.

\section{doi:10.1186/1472-6831-13-35}

Cite this article as: Hafner et al:: Perception of toothache in adults from state capitals and interior cities within the Brazilian geographic regions. BMC Oral Health 2013 13:35.

\begin{abstract}
Authors' contributions
$\mathrm{MBH}$ performed the statistical analysis and drafted the manuscript. JZ participated in the design, and in drafting the manuscript. VLRZ participated in the design of the study. MJB performed the statistical analysis. MLRS participated in its design and coordination, and helped to draft the manuscript. The final manuscript was read and approved by the authors.
\end{abstract}

Received: 7 December 2012 Accepted: 18 July 2013

Published: 31 July 2013

\section{References}

1. Silva JA, Ribeiro-Filho NP: Avaliação e mensuração de dor: pesquisa, teoria e prática. Ribeirão Preto: FUNPEC editora; 2006.

2. Bonica JJ, Loeser JD, Chapman CR, et al: The management of pain. Philadelphia: Lea and Febiger; 1990.

3. World Health Organization (WHO): Preparing patients for invasive medical and surgical procedures: behavioural and cognitive aspects. In Behaviour Science Learning Modules. Geneva: World Health Organization; 1993.

4. Lacerda JT, Simionato EM, Peres KG, et al: Dental pain as the reason for visiting a dentist in a Brazilian adult population. Rev Saúde Pública 2004, 38:453-458

5. Locker D, Grushka M: The impact of dental and facial pain. J Dent Res 1987, 66:1414-1417.

6. Kuhnem M, Peres MA, Masiero AV, et al: Toothache and associated factors in Brazilian adults: a cross-sectional population-based study. BMC Oral Health 2009, 9:7.

7. Costa EB, Carneiro VSM, Pedrosa HLO, et al: Dor de dente: percepção dos usuários da atenção básica de saúde. Odontologia Clín-Científ 2009, 8(1):53-58.

8. Bastos JL, Gigante DP, Peres KG: Toothache prevalence and associated factors: a population-based study in southern Brazil. Oral Disease 2008 $14: 320-326$

\section{Submit your next manuscript to BioMed Central and take full advantage of:}

- Convenient online submission

- Thorough peer review

- No space constraints or color figure charges

- Immediate publication on acceptance

- Inclusion in PubMed, CAS, Scopus and Google Scholar

- Research which is freely available for redistribution 